\title{
Addictive Buying: Causes, Processes, and Symbolic Meanings. Thematic Analysis of a Buying Addict's Diary
}

\author{
Irene García Ureta \\ Universidad del País Vasco
}

The aims of this study were twofold. On the one hand, to reach an understanding of, and to illustrate the experience of addictive buying and, on the other, to throw some light on the controversial subject of addicts' personal responsibility for their behavior. With these aims, a thematic analysis of an extensive diary written by a compulsive buyer is presented. Four themes emerge from the analysis: the defining characteristics of addiction to buying that determine the boundary separating it from other forms of impulsive or careless buying; several causal factors; the role that money and material objects play in family relationships and friendships through the symbolic meanings they adopt; and the relationship of personal values with impulsiveness and self-control. In view of the results, the moral model of addiction to buying is discussed, and an explanatory model of the ambivalence that is characteristic of addiction to buying is proposed, based on a personal hierarchy of values.

Keywords: addiction to buying, compulsive buying, thematic analysis, symbolic consumption, personal values

\begin{abstract}
Con el doble objetivo de, por un lado, comprender y reflejar la experiencia humana de la adicción a la compra, y por otro lado, contribuir a dilucidar la controvertida cuestión de la responsabilidad personal del adicto sobre su comportamiento, se presenta el análisis temático de un extenso diario escrito por una adicta a la compra. Del análisis emergen cuatro temas: las características definitorias de la adicción a la compra que determinan la frontera con otras formas de compra impulsiva o irreflexiva, diversos factores causales, el papel que el dinero y los objetos materiales juegan en las relaciones familiares y de amistad a través de los significados simbólicos que adoptan y la relación de los valores personales con la impulsividad y el autocontrol. Los resultados guían la discusión sobre el modelo moral de la adicción a la compra y fundamentan la propuesta de un modelo que explica la ambivalencia propia de la adicción a la compra sobre la base de la jerarquía personal de valores.

Palabras clave: adicción a la compra, compra compulsiva, análisis temático, consumo simbólico, valores personales
\end{abstract}

This research was supported by grant nr. UPV.016.323-HA056/99 from the Universidad del País Vasco.

Correspondence concerning this article should be addressed to Irene García Ureta. Sarriena s/n. 48940 Leioa. Vizcaya. Spain Telephone.: 94-601-24-14. Fax: 94-601-35-96. E-mail: irene.garcia@ehu.es 
Addiction to buying, also known as compulsive buying, constitutes a compulsive pattern of acquisition of products that is analogous to drug addictions (Echeburúa, de Corral, \& Amor, 2001; Elliot, Eccles, \& Gournay, 1996; Faber, O’Guinn, \& Krych, 1987; Friese, 1999; Rodríguez, 2004), although it is not known at present whether the latter and behavioral addictions are homologous phenomena, that is, whether they share common causal mechanisms (Elster, 1999; Robinson \& Berridge, 2003).

Prevalence studies estimate the scope of the problem in different countries at between $1 \%$ and $7 \%$ of the population (Faber \& O’Guinn, 1992; García, 2005; Koran, Faber, Aboujaoude, Large, \& Serpe, 2006; Reisch \& Scherhorn, 1996; Rodríguez, 2004). However, in western consumer societies, a growing tendency has been noted of buying, which is impulsive, recreational, and compensatory for negative emotional states, and the percentage of consumers who are prone or vulnerable to addiction is estimated to be between $19.5 \%$ and $25 \%$ of the population (Nataraajan \& Goff, 1991; Reisch \& Scherhorn, 1996). These figures indicate the social relevance of this phenomenon, which is not limited to a small percentage of subjects suffering from a mental disorder, but instead reflects a socio-cultural tendency whose medium- and long-term consequences should be considered.

The definitions of addiction to buying include as key characteristics a perceived difficulty in controlling one's impulsive and excessive buying behavior, its chronic nature, its functions of emotional repair and of symbolically improving self-esteem, the development of a strong psychological dependence, and its damaging effects at the economic, psychological, and family levels. Similarly, they point to learning processes as factors that explain the difficulty to control the behavior and its repetitive nature, and they acknowledge vulnerability factors of a cultural, social, situational, and psychobiological nature (Nataraajan \& Goff, 1991; O’Guinn \& Faber, 1989; Rodríguez, OteroLópez, \& Rodríguez, 2001; Rodríguez, 2004).

The above-mentioned perception of difficulty to control, linked to the highly impulsive nature of buying, has led to different and, at times, contrary interpretations of the nature of addictive buying. Whereas in some definitions, it is characterized as irresistible (Black, Monahan, \& Gabel, 1997; Edwards, 1992; Faber \& O'Guinn, 1988; Friese, 1999), other authors relativize that supposed lack of control (Nataraajan \& Goff, 1991), even going so far as to indicate that addictive buying can present characteristics of voluntary behavior (Elliot et al., 1996). This latter point of view has also been defended by other authors in the field of addiction to chemical substances (Megías et al., 2000; Peele, 1987) and of impulsive behavior in general (Baumeister, Heatherton, \& Tice, 1994). These different conceptualizations are directly related to the different conceptual models of addictive behavior and to the issue of addicts' personal responsibility for their own behavior, aspects that I shall develop in this article. I present a thematic analysis of buying addict's diary with an exploratory goal, framed within a wider research project carried out through a survey of a representative sample of the population ${ }^{1}$. The text analyzed, written spontaneously over ten months prior to starting psychological treatment, is an exceptional tool for understanding the experience of addictive buying as it is experienced and interpreted by its protagonist. The qualitative analyses of this phenomenon in the international literature have been scarce (see, for example, Dittmar \& Drury, 2000; Elliot et al., 1996; O'Guinn \& Faber, 1989), and no work has been published in Spain. This is an important gap, as qualitative studies provide a wealth of details and a deep understanding of behavior that are inaccessible to quantitative studies. I therefore believe that this diary provides information of great interest, although it is limited to the study of a single case, which is why my aim is not a representative one but rather seeks to be illustrative and to address the human feature of the phenomenon of addiction to buying.

\section{Conceptual Models of Addictive Behaviors}

Brickman et al. (1982) have described four conceptual approaches to understanding addictive behavior: the moral model, which considers the person responsible both for the start and the solution of the problem; the illuminative model, in which the person is considered responsible for the development of the addiction, but incapable of changing without the help of a "higher power"; the medical model, according to which the person is not held responsible either for the start or the solution of the problem; and the compensatory model, according to which although the person is not responsible for the etiology, change is considered to be a personal responsibility.

\section{Research in Addiction to Buying within the Compensatory Model}

The majority of research in addiction to buying within the compensatory model has identified diverse biological, psychological, and social vulnerability factors that explain how some people evolve from occasional impulsive buying to a compulsive pattern of consumption. Psychological determinants have been the main focus of attention for researchers. In the first place, some characteristics have been identified that reflect a high level of emotional unease, such as anxiety, depression, obsessive-compulsive traits, and low self-esteem. In the second place, we find two closely related

\footnotetext{
1 The complete research can be consulted in García (2005), and the partial results of other sections of the project have been published in García and Olabarri $(2002,2004)$ and Olabarri and García (2003).
} 
behavioral characteristics: impulsiveness and the search for sensations. Finally, another group of characteristics, amongst which are included a low level of responsibility, a style of coping with stress with escape/avoidance strategies and an external locus of control, reflect an individual with few resources to cope adaptively with the demands of the situation (for a review, see García, 2005). With regard to the social factors, family antecedents of diverse addictions, and of addiction to buying in particular, are frequent among addictive buyers (Faber, 1992; Valence, d'Astous, \& Fortier, 1988), but it is not known whether the causal mechanism involved in this relationship is genetic or learned. Various authors have pointed to the importance of family communication processes (Edwards, 1992; Elliot, 1994; Scherhorn, Reisch, \& Raab, 1990), modeling materialist behavior patterns and excessive buying (Cole, 1995). Certain commercial settings, stimuli and "rites" (Christmas, Father's Day, Mother's Day, Valentine's Day, etc.) have been identified as triggers for addictive buying (Christenson et al., 1994; Dittmar, 2000; Faber, 2000). Another growing tendency in consumer societies that is directly related to addiction to buying is the availability of credit (Dittmar \& Drury, 2000; Faber, 2000; McElroy et al., 1994; Roberts \& Jones, 2001).

\section{The Rehabilitated Moral Model}

Although the moral model of addictions has been rejected as an antiquated and unscientific perspective rooted in religion, which, through blame, oppresses and crushes the addict and prevents rehabilitation, at present, the need to reconsider this model is being raised, redefining its bases in scientific terms and recovering the notion of personal responsibility, not only for overcoming addictive behavior but also for its development. Personal and social values and self-control are the bases on which a renewed moral model can be built.

The present developments of this model share a basic premise, according to which the supposedly irresistible nature of addictive or compulsive behavior is no more than an ideological construction, socially fomented and individually assumed by many people. This belief would fulfill a basic function: avoiding responsibility, and it would result in a proliferation or increase in the incidence of this type of behavior, characterized by the immediate satisfaction of one's desires and a lack of consideration for long-term harm or the negative consequences for other people. According to Peele (1987, 1990), individual and cultural values are important determinants of a moderate or excessive style in the consumption of every type of substance. The results of the sociological study carried out in Spain by Megías and his collaborators (Megías et al., 2000) are in agreement with Peele's postulates. The authors conclude that drug consumption is linked to individualistic, hedonistic, and competitive personal and social values and the search for adventure and novelty; on the contrary, humanist, egalitarian, and family values and a conservative attitude deter consumption.
In a conceptualization that links impulsiveness to personal values, Baumeister et al. (1994) proposed that impulses often consist of the transformation of a long-term motivation: They articulate a general interest in the form of a desire to carry out a particular action. The impulses occur at the intersection of general motivations and immediate situations or stimuli. These underlying general motivations can be identified with personal values, defined by Schwartz (1992) as cognitive representations of universal motivations. Deriving from this model, I would propose that, besides the control of stimuli, another mechanism for suppressing impulsiveness is to act on the motivation or the underlying personal values. Similarly, the model of stages and processes of change in addictive behavior (Prochaska, DiClemente, $\&$ Norcross, 1992) proposed that the most effective transition from addiction to non-addictive behavior, either through the addict's own means, or through professional treatment, must start out with becoming aware of oneself and one's problems, and with a re-evaluation of one's values and the effects of the addictive behavior on one's milieu, especially on the people closest to one. Following this process, addicts usually have a high level of motivation to change and high levels of will power and self-confidence in their own potential to overcome the addiction. It is only then that they can put into practice, with some assurance of success or continuity, behavioral strategies such as stimulus control, counterconditioning, or exposure with response-prevention in order to cope with the impulsiveness that is characteristic of addictions (Prochaska, et al., 1992).

The model of Baumeister's (Baumeister et al., 1994) team proposed various factors that weaken self-control. One of them is the conflict of aims: People want to feel good, and when they feel uneasy, the aim of feeling better becomes the central guide of their actions. Thus, when a consumer is debating between saving money or spending it to feel good, emotional unease can alter the balance in favor of making the purchase. Improving one's state of mind takes priority over other goals of self-control, such as saving or doing other things that would have desirable long-term effects. Expectations play an important role in the process: Impulsive buying will take place if the person believes that buying will make her feel better. This role of expectations leads us directly to consider the importance of materialistic values, understood as identifying well-being with the acquisition of material objects. We can therefore see that, according to this model, personal values can be linked, on the one hand, to the origin of the impulses and, on the other, to the failure of self-control when faced with those impulses.

\section{The Relationship of Buying Addiction with Materialism and Personal Values}

Materialistic values have consistently been associated with the development of addiction to buying in numerous studies (Cole \& Sherrell, 1995; DeSarbo \& Edwards, 1996; Dittmar, 
2005; Friese, 2000; García, 2005; Mick, 1996; Mowen \& Spears, 1999; O’Guinn \& Faber, 1989; Rodríguez, 2004). Richins and Dawson (1992) conceptualized materialism as a value, which is expressed in the importance of material objects and their acquisition in a person's life, in identifying happiness, satisfaction, and welfare in one's life with material objects, and in the tendency to judge one's own and other people's success in terms of the number and quality of objects possessed. Drawing on the theory of Schwartz and Bilsky (1987; Schwartz, 1992) on personal values, Burroughs and Rindfleisch (2002) show that materialism is positively related to individualist personal values, and in contrast to collectively oriented values. García (2005) found the same relations of conflict and compatibility between personal values and addiction to buying: positive correlations with individualist power values, and negative correlations with collectivist values of universality and benevolence.

This paper has a double aim. In the first place, it offers a phenomenological description of the experience of the addiction to buying by the author of the diary, which is scrutinized for evidence about the subjects mentioned in this introduction: (a) the defining characteristics of addiction to buying that determine the frontier with other forms of compulsive or careless buying; (b) the personal theories of the diary's author about the causes of her behavior; and (c) indicators of materialistic values and of more general personal values. In the second place, with the aim of developing the moral model, and specifically the model proposed by Baumeister (Baumeister et al., 1994), an analysis is made of the relations of these materialistic personal values with, on the one hand, the degree of compulsiveness in buying and, on the other, the success or failure of self-control when facing such impulses.

\section{Method}

\section{Participant}

The diary analyzed herein was provided by a woman who identifies herself as a buying addict, who was interviewed in the framework of broader research into addictive buying. She was a forty-year-old woman, married, with two children, with a low socio-economic level, and with accumulated, recurrent debts of about 3 million of the old pesetas (18,000 euros) due to her addiction to buying. This person answered an appeal made through several of the mass media in which the problem was explained, the research that was underway was presented, and a contact telephone number was provided.

\section{Material}

This woman began to write the diary when her husband found out about her huge debts and her buying behavior, and she made the firm decision to control her expenses. The diary is 550 pages long and was written spontaneously over ten months, throughout the period prior to the participant starting psychological treatment. It thus has the great value of reflecting her experience with a wealth of detail, her way of understanding addictive buying, and her theories about its causes, without these conceptualizations being influenced by the ideas communicated to her during therapy. The informant tries "to start at the beginning" and tell her story, a process in which she is not held back by any kind of restriction.

\section{Data Analysis}

The orientation of the analysis carried out is based on the phenomenological philosophy and method, which tries to represent consumers' real experience, and to note the aspects of this experience that are present in their awareness. In applying this method, the research seeks to obtain the consumer's testimony that is structured around their own world view, and that represents, as completely as possible, their experiences and beliefs about the phenomenon of consumption involved (Hirschman, 1992).

In their systematization of the experiential perspective, Holbrook and Hirshman (1982) emphasized the need for this type of methodological approach, which gathers introspective reports and free commentaries on conscious cognitive contents. I consider that the analysis of a diary written spontaneously, and with the intention of being exhaustive, is an exceptional tool for understanding the experience of addiction to buying as it is experienced by its protagonist.

In order to identify the recurrent topics in the discourse contained in the diary, I followed the four-step process of analysis recommended by Vallés (1997), termed codification, classification, local integration, and total integration. In repeated readings, annotations were made in the margin indicating the different topics that the passages reflected. Subsequently, I grouped the extracts that referred to a common issue or that were related under a common heading, in order to integrate and interpret each of the analytical categories detected. The result of this first level of analysis is reflected in the section of Results. A subsequent global analysis, relating the results to the theory, allowed me to extract the ideas and general implications that are contained in the Discussion section. The analysis was a process of interpretation, comparison with the theory, and the repeated search for evidence, both favorable and contrary to the meanings extracted from the text.

\section{Results}

The three themes related to my aim of phenomenological description that were clearly revealed in the diary refer to the nature and the defining elements of addictive buying, as understood by someone who has experienced it; the causes 
that provoke it; and the symbolic meanings of the material objects and money that confer compulsive and addictive potential to buying. A fourth theme analyzes the relations of materialistic values with impulsiveness and self-control.

\section{Understanding Addictive Buying}

The author of the diary clearly distinguishes between a purchase that results from an inappropriate spending habit and compulsive buying. The latter is repeatedly described in the diary with the defining characteristics that I will describe in this section.

Buying compulsively is not a synonym of buying a lot, although the latter is a characteristic of addiction to buying. Nor is it only carelessly buying too much, not following a budget, or buying beyond one's means, although such behavior can be an antecedent of, and accompany, addictive buying.

Buying compulsively is described as buying because of "anxiety." This anxiety is characterized as an obsessive desire or impulse, accompanied by some emotional arousal, which varies along two dimensions: its intensity and its positive or negative valence. The intensity of the impulse seems to be related to the class of products: buying inexpensive leisure or food products, and/or products for other people generates less emotional arousal than buying clothes, jewelry, or accessories for oneself.

I like CDs, watches thrill me.

I went to the chemists' and then to the newspaper stall...and I got the feeling of buying, of wanting several books, a toy, and even sets of biros.

I must accept that I feel like buying, and that I do not look at shop windows, but I know there are other fashions and I see this in others. The same thing happens to me, but it's milder, with things for the children and my husband, because I also see things for them.

In turn, the intensity of the impulse determines the difficulty in self-control of buying. She recalls, for example, that she bought "heaps" of crossword magazines. She now realizes that "the most logical thing is to buy them as you do them, it's a different way of spending money." To limit spending on a certain type of product requires no more effort than personal determination:

I have been buying three or four magazines a week. Last week I only bought one.

In contrast, the emotional quality of the impulse seems to be related to the stages of addiction: at first, the desire is pleasurable, whereas in later stages of the addiction, and, above all, in moments of struggling for self-control, the feelings of blame and the perception difficulty to control means that the impulse is felt as an unpleasant, anxious agitation. Most of the experiences of buying seem to be emotionally ambiguous, somewhere between these two extremes.

What used to give me satisfaction, has now become fear, anxiety, I don't know what to call it... Today I bought two frying pans for a friend. Buying is the death of me, since I notice how I feel when buying, and then later it leaves me feeling very tired.

This "anxiety" leads to the purchase of numerous units of the same product, either in a single act of shopping, or in a chain developing over successive days:

Shopping happened by stages: if I went to buy shirts for my son, it had to be four or six, which he does need, but I bought them with anxiety. A dozen pairs of underpants. I don't know how many bags I've got.

Emotional activation and multiple purchases are considered to be important indicators of addiction and therefore of change as well:

I have decided to tell my friend not to say anything to me when he goes shopping, and that he should buy without consulting me, because I have realized that I buy through him, even if it's only telling him the title of a film or of CDs. This can't go on like that, because for me it's bad and I'm scared for him, he likes buying too much, because when he calls and tells me about it, he's all worked up and I get infected by it.

Today I bought a hairgrip... I'm thinking to myself that I've only bought one and I haven't had other temptations, so something's going a little better.

Various metaphors for, or comparisons with, drug addiction are used in the diary:

I would like to have money, I feel anxious; I've got a terrible need to go shopping... I suppose it's as if I'd been addicted to drink or drugs... I've thought about the suit for my son, but it can't be, because it's as if I was drawing on a cigarette.

Buying compulsively means buying illicitly. It means using, as sources of funding, credit cards and loans the husband doesn't know about and that she has no way of repaying.

If it was a year ago, to buy the pills or books, I would go to the cash point and I'd pay for them with money from the credit card. Why did I do that? My husband wasn't going to say anything to me about the books, since he knows how much I like reading, more than TV or any movie. I think it was about going to draw money and always having some available.

For this reason, deceit concerning purchase and expenditure is a constant in her family life.

I used to tell my husband that my mother gave me money and that wasn't so, it was the Visa card... Two rings, which I said I'd found this summer, it's a lie, I bought them... I've got a brown jacket. I told my husband, my niece, my mother, the people who asked me, that a sister-in-law had given it to me.

Concerning the type of products purchased, in consonance with the recent findings of Rodríguez-Villarino, Rodríguez, González, Fernández, and Lameiras (2005), clothes, accessories and jewelry occupy a central position; but almost anything can be bought compulsively, if we consider compulsive any purchase made with a credit card and a motivation of a psychological or symbolic character. This motivation is different according to the kind of 
product: in the case of clothes and accessories, the motivation for buying is related to a desire to improve one's physical appearance, change one's identity, approach an ideal image, nearly always to try to resemble another person.

I don't know, I don't think it was happiness I wanted to buy, instead I wanted to buy myself, change myself... You see some pants that suit you, you buy them, and the first day, OK, the second day nothing, because you go on being you.

Jewelry seems to be tremendously attractive because of its symbolic value as a communicator of status or its aura of luxury.

Yesterday we went to buy sweets at a shop run by a girl who wears the latest fashion, shoes and a lot of jewelry. There was a moment when I thought, looking at what she was wearing: a thick chain with a medallion, a double bracelet on one wrist, three or four fine ones with the watch, which I think is gold on the other, and a lot of rings, besides those I've seen, and that are worth 60,000 pesetas or more. Well, I came to think that I could just as well have things like hers.

The quantity of products bought, the place of purchase, and the form of payment also play a role in the universe of addiction to buying. For example, buying food is considered compulsive if it is bought in great quantities, at a hypermarket, and paying by credit card. These three elements provide a pleasurable experience of freedom from restrictions. If the purchase is of a smaller quantity, in shops or supermarkets, and with hard cash from the weekly wage, then awareness of limitations arises, and although the expenditure may be inappropriate, or not match the budget correctly, it is not classified as compulsive.

I feel very satisfied when I pay with cash and not with a credit card, besides, a small purchase, and I don't feel anything when I see people with full shopping carts. Before, it was a question of completely filling one, or two, it didn't matter... At the hypermarket, I always bought without thinking, twenty or thirty thousand, if there was money I paid the following month, if not, no problem, special payment.

In the case of food, other leisure and low-cost products, and in buying clothes for her husband and children, the dominant motivation seems to be the feeling of power from unlimited spending made possible by the credit card.

Even today, I can't believe that way of spending and spending. Going to the cash point, drawing six thousand pesetas (on credit) to go to the news stand and buying magazines and some knickknacks. Or drawing money to go and buy cakes or a pie because someone was coming home to eat, buying tins, for example, cold cuts, pâté, well, a bit of everything. The thing was to spend on whatever.

Credit cards were my ruin because, at first, paying with money hurt more, but when I started using the credit card, as you don't see the money, everything's wonderful.

Thus, addictive buying has a clearly symbolic nature. That is why, when making a purchase, the evidence presented as proof that this was not compulsive is to enumerate the attributes or functional benefits of the product. Similarly, a cognitive strategy to cope with the compulsive desire is to underline the functionality of the product and deny its symbolic value:

Today I bought a hairpin. It's to make a ponytail with, instead of with a rubber band, it spoils your hair less and is more comfortable.

When I was looking at bags, as my friend was going to buy one, they seemed really nice to me, and I thought, "how nice, but I've already got six or more, different in model and color, so why do I need them? If they all serve the same purpose, for carrying things." I can't understand how one can be so silly.

Some tension arises in addictive buying between the functional and the symbolic, two motives that the diary's author seems to place at opposite extremes of a dimension of legitimacy. Buying with a functional motivation is related to socially acceptable values, such as taking care of the family, maintaining health, or entertainment (food, clothes for one's partner and children, books and magazines, medicines). On the contrary, the symbolism associated with compulsive buying is rooted in values that are considered socially inferior, such as luxury, social status, and power (clothes, jewelry, and accessories for oneself are the products that most clearly seem to be associated with these motivations although, as we have seen, the purchase of any product can acquire symbolic value and shift towards the compulsive pole through payment by credit card).

Addiction to buying means experiencing an obsessive desire to continue buying and to have money, and a great difficulty in resisting the impulse in spite of the adverse consequences and a firm resolve to put an end to such behavior.

I cry because of everything I've been capable of doing, because of everything that must be paid for and, to cap it all, because of the lack of easy money, and, of course, because I can't buy, so my head is in a real muddle.

It's incredible how the compulsion can call out to you, well, call out or remind you of itself. I had started reading enthusiastically and, suddenly, the earrings and the ring that I was going to buy before everything was discovered popped into my mind, and I felt really bad. But I got over it and now I'm feeling good and relaxed.

The reasons to which the author attributes that difficulty in controlling her behavior are made clear in the following extract, in which she makes a comparison with her earlier addiction to tobacco. She explains the significant power motivation that underlies addiction to buying:

I haven't smoked for a year... I've always said that this was going to be harder than giving up smoking, and that's how it is, after a month and a half, more or less, I was pretty much on top of my tobacco habit; however shopping is much harder; there is a saying that goes: better from poor to rich than from rich to poor- how true that is! 
Another important difference with addiction to tobacco is the severity of the long-term economic consequences produced by addictive buying:

When I gave up [tobacco], I felt very bad, my stomach, my head, my nerves, everything. But that's all it was, now, however it's that plus having destroyed the family economy, my husband working like mad.

In her search for the meaning of her behavior, the addictive buyer receives from the mass media and from the health personnel the dominant idea that addiction to buying is a disease beyond personal control, a conceptualization that proceeds from the analogy with drug addiction. This way of understanding their behavior offers buying addicts a clear advantage: it helps them to rid themselves of the blame that often grips them and to mitigate the shame that makes it difficult to openly confront their addiction and to seek help.

I've already talked about what I'm doing here, since everything was discovered I don't think much about it, before it was constant, in that respect, I think I've improved a lot, I feel more useful and I see how what I have is a disease... I worry about what my brothers and sisters-in-law are going to think. I hope they don't think I've done it as a vice or because I'm bad. The truth is that there are times when too many different things are thought.

However, the dominant idea of addiction as a chronic disease imposes a heavy load in the long term that prevents a perspective of happiness in the near and achievable future, which is why it can be overwhelming:

I'm a bit happier today, but my neighbor, who's a nurse, says the same as the doctor, that there's a long way to go and I'll always have to be on the look-out for what I am. The truth is that I stop to think and mine is a rum lot, because it's like being branded... I can't fully take it in.

In short, according to this person's experience, addiction to buying presents a series of characteristics that distinguish it from an occasional pattern of compulsive, careless, or excessive buying, or from buying that simply follows an inappropriate spending habit. In the diary under analysis, the following characteristics emerge as outstanding: addictive buying is accompanied by a high emotional arousal, whose intensity depends on the kind of products and, in turn, determines the difficulty in self-control when faced with the impulse to buy. The pleasant or unpleasant nature of the emotional experience varies over the stages of the addiction. This emotional arousal provokes a pattern of chain-buying and underlies the analogy that the author establishes with drug addiction. Addictive buying is illicit buying with a psychological motivation related to the construction of an idealized identity, the communication of a status or luxury image, and the experience of unlimited power. Addiction to buying thus has a symbolic nature, linked to individualist values such as social status, wealth, and power. Finally, addiction to buying poses a moral problem to the addict, related to both its possible causes and its consequences.

\section{The Process of Buying and Consumption}

The beginning of the process of buying is determined both by internal and external stimuli. Marketing stimuli, such as advertising promotions, can also influence the process of buying, which is characterized, as seen in the previous section, by the acquisition of several units of the same product in a single act of buying or in a chain over several days:

Today there's a fair. My images were: cash point, credit card, me drawing money, and off to the fair to see what I could find to buy. Sometimes, the other way round, I went without any idea of buying, but I would see something and then go home and look for the credit card, draw money, and buy it.

Once I went in to buy some stockings and came out with six pairs, because they were offering three for two.

Amongst the defining elements of addictive buying is its highly impulsive nature. Buying on impulse has been defined by Rook (1987) as a need to buy something immediately, a desire that is sudden and persistent. In their conceptualization of passionate consumption, Belk, Ger, and Askegaard (2003) suggest that the consumer's desire shares with the impulse thus defined its overwhelming character, but not its immediacy and its sudden appearance, as desires persist for long periods of time. Various episodes appear in the diary that respond both to buying on impulse and to the concept of passionate consumption, as they involve a controlled process extending over time:

With respect to the rings that were "found," I saw a neighbor wearing one and liked it. Time passed and I had to go and buy a present. I asked about the rings, saw one, and bought it. When I reached home, I wasn't sure about the purchase. The next day, I went back and changed the ring. Since the one I looked at later was a little cheaper, instead of a credit note, I paid ten thousand pesetas and bought another one. I paid with my Visa Gold card. At other times, a strong emotional arousal at the moment of buying seems to lead to a blockage or altered state of consciousness, which addicts occasionally describe as automatic, unconscious behavior:

Another time I got into buying books. I bought five. I bought anxiously, because I got home and I didn't know what I had bought. Of the five, I bought one knowing what it was about, but not the other four.

The impulse can be very strong, but it can be controlled if it is not possible to conceal the inappropriate nature of the purchase:

Last summer after buying seven pairs of sandals I saw some that cost fifteen thousand pesetas. I didn't buy them because it was the end of the season and I didn't have time to go into town alone. After the others I'd bought, I couldn't go shopping with my friend or my elder child, because I was ashamed, it was too much.

The experience of buying without limits is pleasurable. On the contrary, buying subject to a budget is experienced as highly aversive: 
Going shopping at the hypermarket was blissful, even if it was things for the house, food, soap, and stuff like that, the thing was to buy and pay by credit card.

Today I had a very bad moment. After buying the beach shoes, I asked my niece where I could buy trousers for my son... no one can imagine what I felt when thinking about going in and him wanting some trousers for eight or ten thousand or more and me not being able to buy them. That was unthinkable to me, because, since a few years ago, I don't know what it is like to not buy something for three or four thousand pesetas, because I would just go in and, with the card, it was done.

In the literature, repentance frequently emerges as an important characteristic of addictive buying. In this diary the nature of remorse varies at the diverse stages of the addiction. Repentance of a moral nature, which is expressed in the form of a feeling of blame due to awareness of the damage that is being done to the husband, only appears explicitly and unmistakably after her husband has, for the first time, discovered part of her debts (she continued to conceal the other part) and reacted by facing the economic problem through a credit agreement., After that, when the compulsive purchases were repeated and deceit was unjustifiable in her own eyes, the feeling of guilt was overwhelming:

How hard it is, after paying a huge debt, to go to the shop and buy four or five shirts, three pairs of trousers, a jacket, plus things for the children and my husband. Then, when you're arriving home with it, in recent months you feel bad, it looks bad and moreover you look at your husband and children, you know that you're lying and moreover you feel guilty, you quarrel. Before that stage, repentance referred to dissatisfaction with the products bought because they did not live up to the psychological expectations that motivated the purchase. This results in these products losing their attraction and being abandoned, put away, or given away:

I remember having bought a checked shirt that cost me a lot because someone-I don't remember who-had one like it and was very pretty in it. I thought that if I bought one like it, I'd be the same. I put it on once and liked how I looked, so I went and bought two more. Once I'd put them on a few times, I saw myself looking the same.

The fact that addictive buyers often do not use the products that they buy, they hide them, give or throw them away, has been presented as evidence that the products are unimportant to them, and that, instead, their fundamental motivation lies in the emotions felt during the experience of buying (O'Guinn \& Faber, 1989). This idea has only been explicitly contradicted by Dittmar and Drury (2000). Throughout the diary emerge different patterns of use of the products bought, which range from not wearing them and hiding them in wardrobes to using them frequently, as well as the behavior set out above of using the clothes on a few occasions and, once psychological expectations have not been met, putting or giving them away, to continue searching for a new article that will achieve the miracle.
With respect to the experience of buying, we can also observe an array of feelings ranging from an almost total indifference towards the specific articles bought to a high level of satisfaction with an establishment, related to the gifts received there and the products bought.

I don't know how one can buy beach shoes without liking them and then give them away without wearing them.

I have a favorite shop, because I very much like the clothes they have, and the way they look on me; everything I've bought, which is a great deal, I wear a lot. It's also a shop that gives you a lot of things, because last year they gave my son the Madrid sportswear; it was last year's style, but it was worth eight thousand pesetas, they could have charged me three or four thousand. They also give me socks; the girl there gave me two very nice T-shirts, and this winter, a polo shirt. In short, there are some shops here where I've spent a lot, paying in cash, and not even been given a pair of socks.

Articles are frequently hidden and not used because their purchase cannot be justified before other people, but this does not necessarily mean that the products are not important to the addict. Some addictive buyers turn their houses or bedrooms into temples filled with products that they enjoy alone by means of fantasy, and they are not willing to part with them. On the other hand, the products that the diary's author gets rid of by giving them away tend to be those with a relatively low price, which were bought unthinkingly, obeying a power motivation provided by the unlimited spending of money or the unlimited availability of credit.

In short, the buying episodes can start in response both to internal stimuli (the memory of a product or the desire to experience the sensation that accompanies the purchase pop into the person's mind) and to external stimuli (the sight of the product, a fair, promotions, or offers). Buying can develop impulsively or automatically but frequently, the process that moves from recognition of the desire to effective purchase is long, conscious, and deliberate, without any reference to attempts at self-control appearing at any time. In spite of the buying impulse being experienced with a high level of intensity, it can be controlled when the situation so demands. The factor that provokes control is fear of social censorship when it is impossible to conceal the inappropriate nature of the purchase. The experience of limitless buying produces a pleasurable feeling, whereas buying subjected to a budget produces a sensation of intensely unpleasant frustration. Repentance subsequent to the purchase is very frequent, and adopts different forms at different stages of the addiction, whether due to dissatisfaction with the products bought because of psychological expectations not being met, or to blame and moral reproach towards one's own behavior. This repentance and the fear of social censorship lead to the behavior of storing or getting rid of the products that is typical of addictive buying. 


\section{The Search for Causes}

I have to try and discover why I have done this, that wish to buy, to have money.

The author of the diary discerns several remote causes, related to her family background and her emotional instability, and one immediate cause, which triggered her addictive buying, related to a moment of crisis in her relationship with her husband.

Remote causes: Her family background. With regard to the influence of her family background, three possible interrelated mechanisms are mentioned: genetic heritage, learning and the constitution of her personality, and her emotional imbalance.

I ask myself now whether my problem is inherited, or whether it's what I've seen, or whether I'm a dissolute person. Because my older brothers aren't like that. The women are, though, they lied about shopping, they always said it cost less than it had; well, not when buying food; then, they said it had cost a bit more. The presence of two drinkers and an excessive spender in the family is posed as a possible genetic factor and also as a problem that could have led to her problems of emotional instability.

My family, a total disaster. I don't know to what extent this might have been an influence, a lot, I think. My family was row after row, plus two drinkers, my father and my brother, and the other brother, who, I think, is on the way [of buying], which isn't a good thing at all.

Reckless spending and the repeated recourse to loans to cover debts were constant in the family economy, even before her serious problems with buying started. This, and the habit of deceit about spending, clearly seems to be behavior traits learnt in her parents' home.

I've just remembered my mother paying the bills in installments and in order to pay the rent for where we lived..., they never had money... So I think that I never saw anything that would have served as a good foundation... While I lived with them, my parents never had any savings ... My mother had the habit that, when she bought something a little expensive, she wouldn't tell the truth to Papa, she would say it had cost a little less.

With regard to her personality, the author is torn between the possibility of having inherited an inadequate personality-coherent with her behavior of selfish buying that harms those closest to her, and which generates a strong feeling of guilt - and the idea of being a victim during her childhood and youth of a damaging family setting that has led to pronounced emotional instability, which, in turn, has produced a loss of control over her behavior.

I don't want to seem like a victim, but at the rate I'm going, I'm doing badly. I have the sensation that I'm wrong in the head, or that I'm a pig, like my parents and my little brother. Life has given me a lot of upsets and I'm paying dearly for them; what hurts most is that I'm also a nuisance for my children and, above all, for my husband.
These dual conceptualizations of her behavior, with radically different moral implications, are clearly noted in the following extract:

What I felt wasn't envy, it was complexes and jealousy.

Now, buying was already for the sake of buying, you shift quickly from one thing to the other.

The immediate causes: a moment of crisis in her relationship with her husband. A pattern frequently emerges in descriptions of cases of addiction to buying that can also be observed in this diary: Diverse psychological problems and inappropriate buying and spending habits are the background, or the antecedents, of addiction to buying. But that behavior pattern is habitually triggered in all its severity following a life crisis. In this case, the crisis was caused by her perception of social isolation upon the birth of her second child and aggravated by the prior estrangement from her parental family and her work milieu. The qualitative change in her economic behavior materialized in the start of a private parallel reality of credit and purchases, unknown to her husband, in which there were no limits.

I was left very much alone after the birth of my second child, because of a quarrel with my parents a year before, the row with my brother, then stopping work, getting cut off from my friend. As I didn't have anyone to leave the child with, that put an end to going out and dinners. And not only that, the relationship with our group of friends was nearly completely broken, because we stopped going out, even for a walk. That's when I started to feel bad, lonely, with a complex, I had bad headaches and I didn't have anyone around. Leaving the hospital was terrible... After that, I started to go very fast, because I think I was going slowly at first.

In the eyes of the diary's author, her husband did not provide the help she needed at the time, and that was the determining factor in the start of the buying spiral.

I also have to offer my opinion about my husband, because I think that if he had understood me a little, perhaps some of that could have been avoided... In November, he had a farewell dinner for a friend; well, he went to the dinner, it cost him X amount of money, I don't know how much, but he spent more that night than he had ever spent on his wife and children, all in one go. That hurts a lot when one feels lonely. Well, I didn't stop him from going, instead I said he should find a little time for us. That's where I think the problem started, because he was earning and I was spending.

The author goes on at great length in her description of the lack of consideration, or even abandonment, in her husband's behavior. Although at no point does she explicitly say so in her diary, in various passages, the reader gets the impression that taking revenge on her husband could be one of the factors that triggered the buying spiral.

It really hurt me when, in order to allow him to work at home, I had to take the child out for a walk. He said it wasn't necessary to go out, and well, I don't know if it was, but I felt 
envy and anger on seeing couples and husbands and wives with their children, and me alone. Of course, I continued spending and buying.

This possible motive has already been noted in the literature (Elliot et al., 1996). In this woman's diary, this hypothesis is reinforced by another fact: at the end of the diary, she admits that, in her youth, she stole small quantities of money from her parents in order to take revenge, because they bought her few things and allowed her younger brother to spend without restriction.

In short, the theories of the diary's author about the causes of her behavior replicate fairly exactly the determining factors that diverse empirical studies have identified for addiction to buying. In the diary, she proposes possible genetic causes, and she affirms the role of learning or socialization in consumption and spending, the role of low self-esteem, and the importance of a life crisis in triggering a spiral of buying and spending out of all control. However, the diary points to a possible cause that is lacking in the scientific works, which systematically focus on bio-psycho-social causal factors beyond the individual's control, and considering the subject's will to be annulled. In the diary, when the author analyzes her behavior and its motives, besides the above-mentioned factors, she suggests the possibility that her will is another factor that has guided her behavior when she wonders whether she has inherited an inadequate personality and distinguishes between the motivations for confronting her low self-esteem and "buying for the sake of buying."

\section{The Relationship with Money and Material Objects}

Money and material objects are omnipresent throughout the diary. This is not surprising in a testimony about addictive buying, in which the author describes her economic behavior in great detail. However, the symbolic meanings of products and money, which are sometimes explicitly mentioned and other times are implicit in the author's interpretations of the buying episodes and other life events, reveal some deep-rooted materialistic values. For example:

I admit now that I dreamt of one day shopping in good shops like her [her boss]... A girl friend I had before I got married, who was always dressed in the latest fashion, drew my attention a lot, like the boys who were well dressed. I was mistaken, but nothing can be done about it.

Although, at times, she seems to question the importance of money and material objects, these values constantly emerge. For example, an important motive for worry and anxiety is the damage that her buying behavior has caused to her husband and children. On one occasion, she mentions the possible emotional damage caused by her permanent state of anxiety and irritability; she also considers at one point that her spending habits have not set a good example for her children, but most of the references to this issue refer to the pain she feels because the accumulated debts now prevent her from buying things:
I see people with their flat all set up buy a car, things for their child, and I think how I have ruined my family... It takes a great effort to acknowledge these feelings, like seeing a friend who has kept his money under control and has many more things.

What is outstanding throughout the diary is the degree to which family relationships and friendship revolve around the purchase of products, going to shops as a leisure activity, and gifts, both in the form of material objects and money. One fact that illustrates this centrality is the friendship maintained for years with another buying addict from whom she frequently receives money and gifts.

Money, material objects and presents in family relationships and friendships.

What did I spend money on? On everything and on everyone.

It can repeatedly be seen that purchases, material objects, and money have always been and are present as means of communication and relating, both in family relationships and in friendships. Gifts of articles of clothing and other products to various family members and friends are frequent, not only on special occasions, but as a routine that is carried out either by buying or by paying for what others buy. For example:

This afternoon I went to get clothes for my son, I went with my niece... I think that they have forgotten about that affair of them buying me the suit, but it doesn't matter.

At times, money and presents fulfill a reciprocal function: They are a way of paying for, or returning favors.

When we lived in my parents' house, my mother used to give me money to buy things for the children. They had to keep us happy, because my husband was a godsend to have at home. However, some confusing or identifying love with money or gifts is also noted on more than one occasion.

One day, I had a quarrel with my niece, the one I always said was my child, and the relationship no longer feels the same to me. I feel sorry about the affection and about everything I spent on them. Of course, you must understand that they now have a good friend that gives them a lot, and an aunt without children who is giving them a lot of money, you can see it in their clothes and everything.

The inappropriate nature of her relationships with certain friends, based on excessive gifts, becomes evident to a good friend, someone from outside the family.

Everything we gave them [to other friends] didn't seem right to our friend. When that happened, I was often with the wife of one of these friends. They had a daughter whom I was very fond of. As they didn't have much money I always bought things for the girl, shoes, a dress, a jacket. My friend was right, it was too much.

However, even the clearly excessive gifts from a friend of the family, whom the author at one point admits is probably also a buying addict, seem to be accepted as normal within her close family, that is, by her mother and her husband: 
For my birthday, I went to the shop and I really took advantage of this friend, because he pays by installments. I bought a jacket, a skirt, a jersey, a jacket with a polo shirt, and, to round it off, two pairs of pants because last year's pants are no use to me...The other day, I told my husband what I had spent on the coat at Epiphany: seventy-two thousand I think it was, "our friend's Epiphany" I called it; he never put a limit on my spending.

The fact that her husband and the people in her milieu did not consider these gifts to be unacceptable can only be understood if the constant presence of gifts and money in family relationships is recalled. In fact, this friend's gifts include clothes and other products for the husband and children. These family values, beliefs, and customs with respect to money and material objects, in short, the predominant material culture in this family generates an atmosphere of permissiveness that favors the development of addictive buying. For example:

When our little boy was born, my parents paid off a small debt for me: I owed 150,000 pesetas.

At the time of writing the diary, her mother continues to give her, as always, some money on each visit, between 5,000 and 7,000 pesetas. The behavior of both women during these visits reminds one of a relationship with a child, a nephew or niece, or a grandchild, because each time there is a visit, there is always, or nearly always, "pocket money":

Today, my mother came to bring me prescriptions, well, I was waiting to see if she would give me something... she gave me five thousand pesetas.

Whereas at no point does the author of the diary seem to question whether this way of relating to her mother is appropriate or not, at a point well into writing the diary, she does seem to become somewhat aware of the inappropriateness of basing her relationship with her nephews and nieces on money:

I'm going to draw a thousand pesetas for today or tomorrow because my nephews and nieces are coming. I draw a thousand because there are three of them and they'll spend it on the machines, if not, I'd only take five hundred.

The next day she writes:

I drew a thousand pesetas yesterday. I've got them in my wallet unchanged; I didn't even give a single coin to the kids.

\section{The Symbolic Nature of Money}

Like material objects, money can fulfill different psychological functions linked to self-esteem through the symbolic meanings it adopts, related to social status, power, security, freedom, love, and personal satisfaction (Hanley $\&$ Wilhelm, 1992). Some of these meanings can be observed in the following passage:

I think that if last year I didn't confess everything, apart from it being a lot, it was also because I knew what was going to happen, an end to credit cards, money totally controlled, and a stop to buying, you have to realize that, when you put it like that, it seems impossible, living with only small change in your bag, not having money at hand, not being able to go to the cash point and from there, to spend a thousand pesetas on magazines and another thousand on silly things. Not carrying money around to spend stupidly. Not having money to give to the nephews and nieces.

A clear dichotomy is established between income proceeding from her husband's salary and the money from credit cards or other sources, concretely, the various sums that are given to her periodically by her mother and her friend, the buying addict. This distinction enables her to keep her addiction within certain limits while respecting what is most sacred in spite of everything, and thus, to some extent, saving her self-esteem:

What is turning out to be a victory, something great for me, is that I have money left over at the end of the week and without having used the Visa card. I wonder what I did before, because I swear by my children that I didn't take anything from the weekly money to pay off any of my debts; that is, the loans I had, nor for buying, sandals, for example.

The psychological response to spending money from one source or another is radically different: spending subject to a budget awakens awareness of limits, and this is experienced as especially painful because it clashes directly with some power motivation:

This morning, from six-thirty onwards, I didn't get back to sleep. Well, at midday I started to think about it, because something was happening to me. It takes a lot to acknowledge it, because feeling this after three months is demoralizing, but, well, that's the way it is ... This morning it was going to the hairdresser's, because it means going out and spending... How sad and how it hurts to have to depend on money.

Spending on credit, whether paying with a credit card or in cash after drawing money on credit from a cash point, was not something to which she was indifferent; instead it provoked a pleasant emotional reaction, linked to the experience of power provided by the unlimited availability of money. In itself, this emotional experience constitutes a motivation for compulsive shopping which can be as important as the attempt to appropriate the symbolic value of products through their purchase.

The two terms used to refer to the illicit money from credit cards ("easy money," "money that isn't mine") well reflect the moral conflict she faces:

I cry because of everything I've been capable of doing, because of everything that must be paid for and, to cap it all, because of the lack of easy money, and, of course, because I can't buy, so my head is in a real muddle.

I've still got to get through Sunday, it's going to be bad, but I'm going to look on the bright side, which is that I'm going without hiding anything and without money that isn't mine, I mean from the cash point. It's the first time that we're going there, and me with my wallet almost empty. I have to see it like that, to look on the good side. 
The possession of hard cash or the awareness of having credit provides a sensation of security and control. On the contrary, the awareness of scarcity generates great anxiety:

I always had to have 10,000 pesetas or more in the pocket of a jacket I keep in the wardrobe that I hardly ever wear, if not, I wasn't comfortable, I was lacking something, it was a feeling of desperation.

When my credit card had almost reached its limit, it was horrific, until I got used to the idea that I couldn't draw much more on that one now, although I had another card with 100,000 pesetas.

In short, materialistic values are implicit in a great many passages of this diary, and the family appears to be immersed in a culture in which objects and money are used as privileged means of communication and relating. On occasions, they fulfill a reciprocal function, but they also lead to confusing and identifying love with money and gifts. These habits and beliefs seem manifestly inappropriate to someone from outside the family circle, but their acceptance within the family generates an atmosphere of permissiveness that facilitates the development of addictive buying. Money and spending acquire a symbolic meaning, they trigger emotional reactions and they fulfill psychological functions similar to those of material objects. The resort to illicit money and respect for family money are used as a selfimposed limit on the addiction, allowing some protection of self-esteem.

\section{Relationship between Personal Values and Impulsiveness and Self-Control}

Throughout the diary, materialistic values are related to impulsiveness in two ways. In the first place, the intensity of the buying impulse is determined by the symbolism associated with the products considered: products that convey an image of status, luxury, or an idealized identity, together with credit cards - symbols of an unlimited power-produce great emotional arousal that makes self-control difficult. In the second place, when the diary's author compares the difficulty of controlling her earlier addiction to tobacco with her present addiction to buying, she considers it more difficult to give up money and status than to cope with the symptoms caused by abstinence from nicotine.

On the other hand, materialistic values and their reevaluation lie at the root of success or failure of self-control in addiction to buying. The narrative of the crisis when her husband first discovered part of her debts, while she continued to conceal the rest, and later continued with her addiction, represents a failure in self-control that the protagonist attributes to the fact that, when weighing up the pros and cons of abandoning or continuing her addiction, materialistic values prevail which make giving up unlimited money seem unbearable.

At that moment, the author of the diary is at the contemplation stage of addiction, in terms of Prochaska et al.'s (1992) model. In her story, it is evident that reevaluation of her hierarchy of personal values is a key point in the transition towards the stage of action, the moment when the addiction is effectively confronted and self-control is achieved. At this moment, which is marked by starting to write the diary, and later, throughout the phase of maintenance (in which she strives to avoid relapses and to consolidate the change in her behavior) one can observe her questioning her materialistic values. Thus, she now considers the importance she previously attributed to clothes to have been a mistake, she renews her relationship with her nephews and nieces and avoids giving them money, and she reinterprets the nature of money on credit in moral terms ("easy money," "money that isn't mine"). From this point onwards, and on this basis, the self-control techniques that an addict spontaneously puts into practice begin to be effective, both stimulus control (avoiding looking in shop windows, altering her relationship with a friend, a probable buying addict) and the cognitive strategy of underlining the functionality of products and ignoring their symbolic value.

\section{Discussion}

The results show the relevance of materialistic values to understand impulsiveness and the success or failure of self-control in addiction to buying, and can be added to the evidence supporting the rehabilitation and renovation of the moral model of addiction. Earlier studies uncovered biological variables, personality characteristics, psychological disorders, and social factors that determine vulnerability to addictive buying. The moral model draws attention to the influence of cultural values and their representation in individuals' personal hierarchy of values, a factor that has not received the necessary attention. Baumeister et al. (1994) warn that consumer culture, within which credit cards should be underlined, overwhelms individuals with stimuli that trigger impulsive buying, at the same time as reinforcing materialistic values, thus fomenting a proliferation of very powerful impulses against which great power or energy is required for self-control. The confluence of this materialistic culture and the cultural sanction of the irresistible nature of impulses can only foment addiction to buying.

On the other hand, ambivalence has been noted as a key characteristic of addiction: in the addicted person, there is a conflictive coexistence of the desire for the drug, or for carrying out addictive behavior, with the rational consideration of the appropriateness of abandoning the habit in the light of its harmful consequences (Elster, 1999). The most recent neurological studies have observed some biological reasons for this ambivalence and for the great difficulty experienced by addicts to diverse drugs to stop consumption. These neurological explorations suggest that neural sensitization, that is, the neural adaptations produced by addictive drugs, can lead to a pathological desire to 
consume the drug. However, given that the neural systems responsible for the desire are different from those related to the hedonistic effects of the drugs, the paradoxical effect of a desire for the drug that has no relation to the pleasure obtained from it can be produced. This pathological desire can persist in spite of the addict's awareness that the drug does not give pleasure and it can impose itself on other rational and stable life priorities that the individual declares to be his explicit aims (Robinson \& Berridge, 2003). Although it is not known whether a similar effect of neural sensitization is produced in addiction to buying, the subjective experience of the diary's author is in close keeping with the previous description.

This ambivalence or contradiction, and the dominance of desire or feelings over reasoning, have been presented as the hallmark of addiction (Elster, 1999), that is, as one of its defining characteristics. This forms the basis of the difficulty of control that qualitatively differentiates the addict's characteristic irrational behavior from normal behavior. However, recent psychosocial and neurobiological theories of moral judgment state that, when it comes to making judgments in diverse situations, the primacy of feelings over logical reasoning is the norm, not the exception (Haidt, 2001; Greene, Sommerville, Nystrom, Darley, \& Cohen, 2001). Furthermore, in analyses of behavior considered to be normal, it is postulated that emotions and intuitions are better predictors of behavior than reasoning (Haidt, 2001). People's judgments are frequently intuitive, rapid, easy and holistic. Only when there is conflict between different intuitions that arise in the same situation, or when someone demands an explanation from the person, is the process of reasoning activated - an intentional, costly, conscious, and controllable search for evidence consistent with the judgment or behavior emitted. However, what is sought is not the recall of the cognitive processes that led to the judgment or behavior, because these processes are not consciously accessible. Actually, what is sought are plausible theories about the reason for the judgment or behavior, for which the person resorts to the set of norms and explanations of behavior supplied by culture.

Elaborating on the results, I suggest an adaptation of this theory to understand addiction to buying: I propose that personal values, that is, the predominant motivations, can both determine automatic emotional reactions when facing stimuli and buying situations, and immediate judgment, also automatic, about the appropriateness or need of buying. Subsequent reasoning-which takes into account the dominant cultural and social values (which can be represented at a lower level on the hierarchy of personal values) — can clash with the initial intuition and judgment, leading to a psychological conflict prior to the purchase and to a reaction of regret following it. However, the purchase is probable, given that behavior is closely related to intuitions and automatic judgments.
Thus, self-control over impulsiveness in buying requires a real change of the personal hierarchy of values. This assertion is coherent with the model of stages and processes of change in addictive behavior and other problematic behavior proposed by Prochaska's team (Prochaska, 1994; Prochaska et al., 1992). According to this model, cognitive and motivational restructuring is required to provide addicts with the necessary will-power and self-confidence if they are to benefit from other techniques to control impulsive behavior, such as stimulus control, counter-conditioning, or exposure to stimuli with response prevention.

This work is the first attempt to analyze the relationship between personal values and addiction to buying. The results indicate that this could be a promising path of research, and encourages me to suggest the development of future research projects with a predictive goal. Subsequent works could attempt to answer the question of whether, among people with a high predisposition to addiction to buying due to their biological, psychological, or sociological characteristics, the hierarchy of personal values to some extent determines successful control of impulses in some of them, whereas others slide down a hill that will finally result in harmful consequences, both for themselves and for their close family and friends. Similarly, analysis of the possible modifications in the personal hierarchy of values in the various stages of change in addictive buying would constitute a valuable contribution to the above-mentioned model, and a method of validation of the theoretical contribution that I have tried to make in this article.

\section{References}

Baumeister, R.F., Heatherton, T.F., \& Tice, D.M. (1994). Losing control: How and why people fail at self-regulation. San Diego, CA: Academic Press.

Belk, R.W., Ger, G., \& Askegaard, S. (2003). The fire of desire: A multisided inquiry into consumer passion. Journal of Consumer Research, 30, 326-351.

Black, D.W., Monahan, P., \& Gabel, J. (1997). Fluvoxamine in the treatment of compulsive buying. Journal of Clinical Psychiatry, 58, 159-163.

Brickman, P., Rabinowitz, V.C., Karuza, J., Coates, D., Cohn, E., \& Kidder, L. (1982). Models of helping and coping. American Psychologist, 37, 368-384.

Burroughs, J.E., \& Rindfleisch, A. (2002). Materialism and wellbeing: A conflicting values perspective. Journal of Consumer Research, 29, 348-370.

Christenson, G.A., Faber, R.J., De Zwann, M., Raymond, N.C., Specker, S.M., Ekern, M.D., Mackenzie, T.B., Crosby, R.D., Crow, S.J., Eckert, E.D., Mussell, M.P., \& Mitchell, J.E. (1994). Compulsive buying: Descriptive characteristics and psychiatric comorbidity. Journal of Clinical Psychiatry, 55, 5-11.

Cole, L.K. (1995). Modeling the antecedents of compulsive buying. Doctoral dissertation, Louisiana State University, Baton Rouge, 
Cole, L., \& Sherrell, D. (1995). Comparing scales to measure compulsive buying: An exploration of their dimensionality. Advances in Consumer Research, 22, 419-427.

DeSarbo, W.S., \& Edwards, E. A. (1996). Typologies of compulsive buying behavior: A constrained clusterwise regression approach. Journal of Consumer Psychology, 5, 231-252.

Dittmar, H. (2000). The role of self-image in excessive buying. In A.L. Benson (Ed.), I shop therefore I am: Compulsive buying and the search for self (pp. 103-132). Northvale, NJ: Jason Aronson.

Dittmar, H. (2005). Compulsive buying—a growing concern? An examination of gender, age, and endorsement of materialistic values as predictors. British Journal of Psychology, 96, 467-491.

Dittmar, H., \& Drury, J. (2000). Self-image—is it in the bag? A qualitative comparison between "ordinary" and "excessive" consumers. Journal of Economic Psychology, 21, 109-142.

Echeburúa, E., de Corral, P., \& Amor, P.J. (2001). ¿Cómo y por qué se desarrollan las adicciones sin drogas? In I. García \& E. Olábarri (Eds.), El consumo y la adicción a las compras. Diferentes perspectivas. Leioa, Spain: Universidad del País Vasco.

Edwards, E.A. (1992). The measurement and modeling of compulsive consumer buying behavior. Doctoral dissertation, University of Michigan, Ann Arbor.

Elliot, R. (1994). Addictive consumption: Function and fragmentation in postmodernity. Journal of Consumer Policy, $17,159-179$.

Elliot, R., Eccles, S., \& Gournay, K. (1996). Revenge, existential choice, and addictive consumption. Psychology and Marketing, 13, 753-768.

Elster, J. (1999). Strong feelings: Emotion, addiction and human behavior. Cambridge, MA: MIT Press.

Faber, R.J. (1992). Money changes everything: Compulsive buying from a biopsychosocial perspective. American Behavioral Scientist, 35, 809-819.

Faber, R.J. (2000). A systematic investigation into compulsive buying. In A.L. Benson (Ed.), I shop therefore I am: Compulsive buying and the search for self (pp. 27-53). Northvale, NJ: Jason Aronson.

Faber, R.J., \& O'Guinn, T.C. (1988). Compulsive consumption and credit card abuse. Journal of Consumer Policy, 11, 97-109.

Faber, R. J. \& O'Guinn, T. C. (1992). A clinical screener for compulsive buying. Journal of Consumer Research, 19, 459-469.

Faber, R.J., O’Guinn, T.C., \& Krych, R. (1987). Compulsive consumption. Advances in Consumer Research, 14, 132-135.

Friese, S. (1999). Addictive buying. In P.E. Earl \& S. Kemp (Eds.), The Elgar companion to consumer research and economic psychology. Cheltenham, UK: Edward Elgar.

Friese, S. (2000). Self-concept and identity in a consumer society. Aspects of symbolic product meaning. Marburg, Germany: Tectum Verlag.

García, I. (2005). La adicción a la compra en Bizkaia. Un estudio empírico de su relación con los valores personales. Doctoral dissertation. University of the Basque Country, San Sebastián, Spain.
García, I., \& Olábarri, E. (2002). Experiential consumption and excessive impulse buying. A new typology of consumers. In ESOMAR (Ed.), Consolidation or renewal? From research to customer insight. Proceedings of the ESOMAR Congress 2002 (pp. 119-143). Amsterdam: The World Association of Research Professionals.

García, I., \& Olábarri, E. (2004). The addiction to shopping and personal values. In J.L. Munuera-Alemán, (Ed.), Worldwide marketing? Proceedings of the 33rd EMAC Conference, Murcia, Spain: European Marketing Academy.

Greene, J.D., Sommerville, R.B., Nystrom, L.E., Darley, J.M., \& Cohen, J.D. (2001). An fMRI investigation of emotional engagement in moral judgment. Science, 293, 2105-2108.

Haidt, J. (2001). The emotional dog and its rational tail: A social intuitionist approach to moral judgment. Psychological Review, $108,814-834$.

Hanley, A., \& Wilhelm, M.S. (1992). Compulsive buying: An exploration into self-esteem and money attitudes. Journal of Economic Psychology, 13, 5-18.

Hirschman, E.C. (1992). The consciousness of addiction: Toward a general theory of compulsive consumption. Journal of Consumer Research, 19, 155-179.

Holbrook, M.B., \& Hirschman, E.C. (1982). The experiential aspects of consumption: Consumer fantasies, feelings, and fun. Journal of Consumer Research, 9, 132-140.

Koran, L.M., Faber, R.J., Aboujaoude, E., Large, M.D., \& Serpe, R.T. (2006). Estimated prevalence of compulsive buying behavior in the United States. American Journal of Psychiatry, 163, 1806-1812.

McElroy, S.L., Keck, P.E., Harrison, G., Pope, M.D., Smith, M.R., \& Strakowski, S.M. (1994). Compulsive buying: A report of 20 cases. Journal of Clinical Psychiatry, 55, 242-248.

Megías, E., Comas, D., Elzo, J., Megías, I., Navarro, J., Rodríguez, E., \& Romaní, O. (2000). Los valores de la sociedad española y su relación con las drogas. Colección Estudios Sociales (2). Fundación La Caixa. Retrieved at: http://www.estudios.lacaixa. comunicacions.com/webes/estudis.nsf/wurl/pfes002cos_esp

Mick, D.G. (1996). Are studies of dark side variables confounded by socially desirable responding? The case of materialism. Journal of Consumer Research, 23, 106-119.

Mowen, J.C., \& Spears, N. (1999): Understanding compulsive buying among college students: A hierarchical approach. Journal of Consumer Psychology, 8, 407-430.

Nataraajan, R., \& Goff, B.G. (1991). Compulsive buying: Towards a reconceptualization. Journal of Social Behavior and Personality, 6, 307-328.

O'Guinn, T.C., \& Faber, R.J. (1989). Compulsive buying: A phenomenological exploration. Journal of Consumer Research, 16, 147-157.

Olábarri, E., \& García, I. (2003). La compra por impulso y la adicción al consumo en el País Vasco. Estudios sobre Consumo, 65, 53-67.

Peele, S. (1987). A moral vision of addiction: How people's values determine whether they become and remain addicts. The Journal of Drug Issues, 17, 187-215. 
Peele, S. (1990). A values approach to addiction: Drug policy that is moral rather than moralistic. The Journal of Drug Issues, 20, 639-646.

Prochaska, J.O. (1994). Strong and weak principles for progressing from precontemplation to action on the basis of twelve problem behaviours. Health Psychology, 13, 47-51.

Prochaska, J.O., DiClemente, C.C., \& Norcross, J.C. (1992). In search of how people change. Applications to addictive behaviors. American Psychologist, 47, 1102-1114.

Reisch, L.A., \& Scherhorn, G. (1996). Women and addictive buying: Theory and research. Stuttgart: Universität Hohenheim.

Richins, M.L., \& Dawson, S. (1992). Materialism as consumer value: Measure development and validation. Journal of Consumer Research, 16, 147-157.

Roberts, J.A., \& Jones, E. (2001). Money attitudes, credit card use, and compulsive buying among American collage students. Journal of Consumer Affairs, 35, 213-240.

Robinson, T.E., \& Berridge, K.C. (2003). Addiction. Annual Review of Psychology, 54, 25-53.

Rodríguez, R. (2004). Naturaleza y alcance de la adicción a la compra en la población urbana de Galicia: un estudio empírico. Doctoral dissertation. University of Vigo, Spain.

Rodríguez, R., Otero-López, J.M., \& Rodríguez, R. (2001). Adicción a la compra. Análisis, evaluación y tratamiento. Madrid: Pirámide.
Rodríguez-Villarino, R., Rodríguez, R., González, M., Fernández, A., \& Lameiras, M. (2005). ¿Qué productos se asocian a la compra adictiva? Una aproximación al binomio producto-adicto. Estudios sobre Consumo, 75, 65-77.

Rook, D.W. (1987). The buying impulse. Journal of Consumer Research, 14, 189-199.

Scherhorn, G., Reisch, L., \& Raab, G. (1990). Addictive buying in West Germany: An empirical study. Journal of Consumer Policy, 13, 355-387.

Schwartz, S.H. (1992). Universals in the content and structure of values: Theoretical advances and empirical tests in 20 countries. Advances in Experimental Social Psychology, 25, 1-65.

Schwartz, S.H., \& Bilsky, W. (1987). Toward a universal psychological structure of human values. Journal of Personality and Social Psychology, 53, 550-562.

Valence, G., d'Astous, A., \& Fortier, L. (1988). Compulsive buying: Concept and measurement. Journal of Consumer Policy, 11, 419-433.

Vallés, M.S. (1997). Técnicas cualitativas de investigación social. Reflexión metodológica y práctica profesional. Madrid: Síntesis Sociología.

Received July, 11, 2006

Revision received March, 13, 2007

Accepted April, 25, 2007 